\title{
Accretionary models for the Neoproterozoic evolution of the Borborema Province: advances and open questions
}

\author{
Lauro Cézar Montefalco de Lira Santos ${ }^{1 *}$ (D), Fabricio Caxito ${ }^{2}$ (D)
}

\begin{abstract}
The current knowledge on the accretionary evolution of the Borborema Province is evaluated considering recently published data and interpretations. Early to late Neoproterozoic eclogite, ophiolite, and magmatic arc remnants have been documented and point to oceanic crust consumption. Isotopic contrasts as well as geophysical anomalies across the major domain boundaries are suggestive of collisional sutures and a speculative model of terrane accretion is presented here. On the other hand, the lack of concise evidence for some of the proposed deep-seated structures as well as putative lithospheric continuity in both sides of it suggest reworking of previously continuous lithosphere through intracontinental deformation in localized sectors of the province interior. It is patent that one model does not preclude the other and available evidence so far has triggered the emergence of conciliatory proposals for the Neoporterozoic history the Borborema Province.
\end{abstract}

KEYWORDS: accretion tectonics; Neoproterozoic terrane assembly; Borborema Province.

\section{INTRODUCTION}

The lack of consensus on how Earth dynamics have operated through time feeds warm debates in the scientific community. Famous unresolved issues include models for granitic emplacement in the crust (Cruden and Weinberg 2018), the nature of the Archean tectonics (Van Hunen and Moyen 2012), the role of mantle plumes (French and Romanowicz 2015), and the different modes of subduction as a consequence of secular mantle cooling (Brown and Johnson 2019).

The same is true for the Neoproterozoic orogens of South America. For instance, multiple collision models have been proposed for the Ribeira Orogen in SE Brazil (e.g. Heilbron et al.2008), but despite the tight geological, geochemical, and geochronological constraints provided in these models, recent studies have returned to pre-1990's proposals of intracontinental settings (e.g. Meira et al. 2019). The Borborema Province (BP; NE Brazil), like other Neoproterozoic orogenic areas of Brazil, is part of the large system proposed by Almeida et al. (1981), built-up through convergence of the São FranciscoCongo and São Luis-West African paleocontinents during the Brasiliano Orogeny (ca. 630--530 Ga; Brito Neves et al. 2014, Caxito et al. 2020a).

Terrane accretion models (sensu Coney et al. 1980) have been proposed to explain strong geological and geophysical

\footnotetext{
${ }^{1}$ Departamento de Geologia, Universidade Federal de Pernambuco Recife (PE), Brazil. E-mail: lauro.lsantos@ufpe.br

${ }^{2}$ Centro de Pesquisas Professor Manoel Teixeira da Costa, Instituto de Geociências, Universidade Federal de Minas Gerais - Belo Horizonte (MG), Brazil. E-mail: caxito@ufmg.br

${ }^{*}$ Corresponding author.
}

(c) 2021 The authors. This is an open access article distributed under the terms of the Creative Commons license. contrasts between major shear zone-bounded domains (e.g. Santos and Medeiros 1999, Brito Neves et al. 2000), whereas intracontinental mechanisms were proposed to explain the lack of contrast between some of these domains (Neves 2003). New alternatives proposing both the acting of typical modern-style plate tectonics processes and reworking of older basement blocks in the interior of the province have emerged (e.g. Oliveira et al. 2010, Ganade de Araújo et al. 2014a, Caxito et al. 2016,2020a) reinforcing some aspects of previous models and highlighting problems that have not yet been detected or discussed. The goal of this contribution is to present an update of ideas mainly related to the accretionary model since the seminal work of Santos (1996) and future perspectives for the evolutionary dynamics of the BP.

\section{GEOLOGICAL SETTING}

The BP corresponds to the Neoproterozoic northeastern portion of the South American Platform. It comprises a series of crustal blocks bounded by thrust- and strike-slip shear zones, that led Van Schmus et al. (1995) to divide it in northern, central, and southern subprovinces. In West Gondwana reconstructions, the province represents the easternmost segment of the Brasiliano orogens that were connected to Pan-African orogenic belts (Caxito et al. 2020a and references therein) along Nigeria, Cameroon, Togo, and Benin (Fig. 1).

Following the former subdivisions of the province (Santos 1996, Brito Neves et al. 2000), in a simplified way, the northern subprovince is divided into Médio Coreaú, Ceará Central, Orós-Jaguaribe, and Rio Grande do Norte domains, whereas the Central Subprovince is divided into the sigmoidal-shaped São Pedro, Piancó-Alto Brigída, Alto Pajeú, Alto Moxotó, and Rio Capibaribe terranes. The Pernambuco-Alagoas domain is a relatively stable block, interpreted as the result of several 
terrane collision episodes during the Paleoproterozoic and early Neoproterozoic (Silva Filho et al. 2016, Brito Neves and Silva Filho 2019), and together with the Sergipano, Riacho do Pontal, and Rio Preto belts, comprises the southern subprovince framework.

Due to episodes of deformation, metamorphism, and magmatism spanning the entire Precambrian, the geological settings of the Boborema Province are variable and complex. It presents a series of Archean (ca. 3.75-2.7 Ga; Dantas et al. 2013, Ganade de Araújo et al. 2017, Santos et al. 2017a, Lima et al. 2019) and Paleoproterozoic blocks/terranes (ca. 2.2-2.0 Ga; Hollanda et al. 2011, Caxito et al. 2015, Santos L.C.M.L. et al. 2013 , 2015) mostly bounded by Neoproterozoic metavolcanosedimentary domains generated during the Cariris Velhos (ca. 1,000-920 Ma) and Brasiliano (ca. 630-500 Ma) events (Brito Neves et al. 2000, Santos et al. 2010).

The vast network of shear zones is one of the most remarkable features of the BP, representing deformation stages in variable crustal levels (Archanjo et al. 2008, Viegas et al. 2014), including deep-seated structures with characteristic geophysical signatures, such as the lithospheric Transbrasiliano suture (Cordani et al. 2013, Oliveira and Medeiros 2018). Late Neoproterozoic plutonism is widespread and comprises the whole-spectrum of subduction-related magmas, involving normal to high-K calc-alkaline granites dated at ca. 640-600 Ma; high-K calc-alkaline and shoshonitic granites dated at 590-580 Ma; post-collision alkaline granites dated at ca. $570 \mathrm{Ma}$; and anorogenic granites aged at ca. 540-510 Ma (Guimarães et al. 2004, Ganade de Araújo et al. 2014b, Sial and Ferreira 2016, Santos et al. 2020).

\section{THE CASE FOR AN ACCRETIONARY MODEL}

Following the original premises of Howell (1995), which were constantly updated over the years ( Tetreault and Buiter 2014), elements of accretion tectonics necessarily involve the consumption of oceanic crust. Regarding Precambrian orogens, direct evidence for ancient oceans such as ophiolite remnants are rare and susceptible to erosion, reworking, and dismemberment due to later deformation, and in the case of the $\mathrm{BP}$, lateral strike-slip dislocation. It is not rare that the site of ancient oceans is now marked as "dry" suture zones (i.e., whose ophiolitic remnants have been eroded away in upper crustal sections). Nevertheless, other elements might be used as evidence for tectonic juxtaposing of blocks with distinct

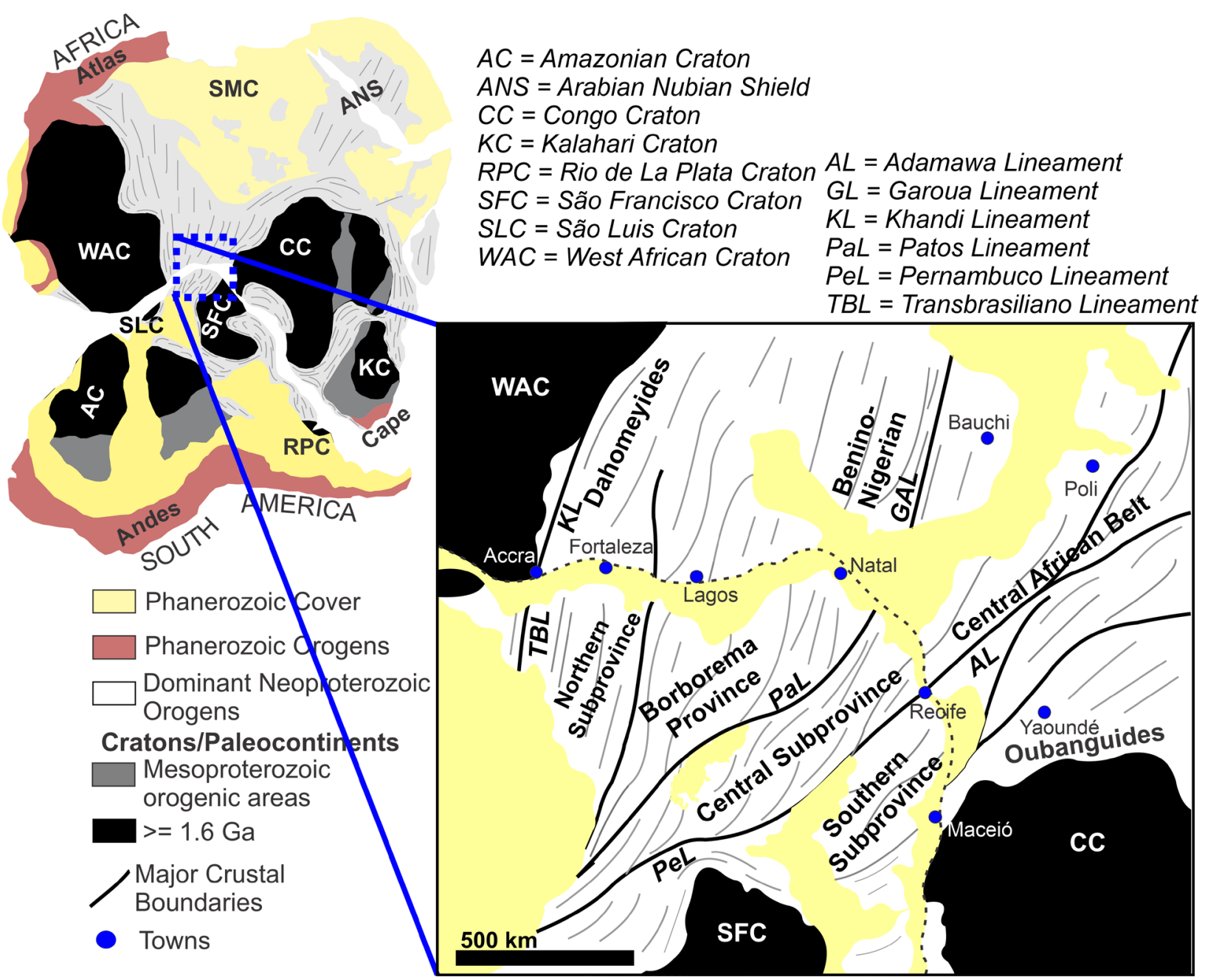

Figure 1. Pre-drift reconstruction of the Borborema Province in the West Gondwana context and its correlation with major West African orogenic belts. 
geological, geophysical, and isotopic characteristics, and to reconstruct the orogenic history of an area (Brito Neves 2019) as in the case of the BP (Figs. 2 and 3 ).

Recent advances in accretionary models for distinct portions of the BP are mostly based on petrological-isotopic and geophysical evidence. One of the best constrained areas with evidence for oceanic lithosphere consumption is the Ceará Central Domain of the Northern BP and its limits with the Medio Coreaú domain northern ward. Ultrahigh-pressure metamorphism in the Forquilha region in westernmost Ceará Central is constrained by the occurrence of coesite and atolltype garnet crystals in metamafic rocks, representing a transition from eclogite to amphibolite facies between 640 and
$614 \mathrm{Ma}$ (Amaral et al. 2011, 2012, Santos T.J.S. 2015). Highpressure to ultrahigh-pressure metamorphism has also been documented on coeval eclogites from Mali and Togo, leading Ganade de Araújo et al. (2014a) to suggest that deep-continental subduction took place in the region. The Forquilha eclogites occur between the Santa Quitéria magmatic complex to the east, that has long been proposed as a CryogenianEdiacaran (660-620 Ma) continental arc (Fetter et al. 2003) and the Transbrasiliano-Kandi megashear zone, that crosses the Brazilian territory from the Pantanal area up to the Hoggar region of the Transaharan orogen in NW Africa in pre-drift reconstructions (Cordani et al.2013, Caxito et al. 2020a). The west-to-east pairing of megashears, eclogite remnants, and a

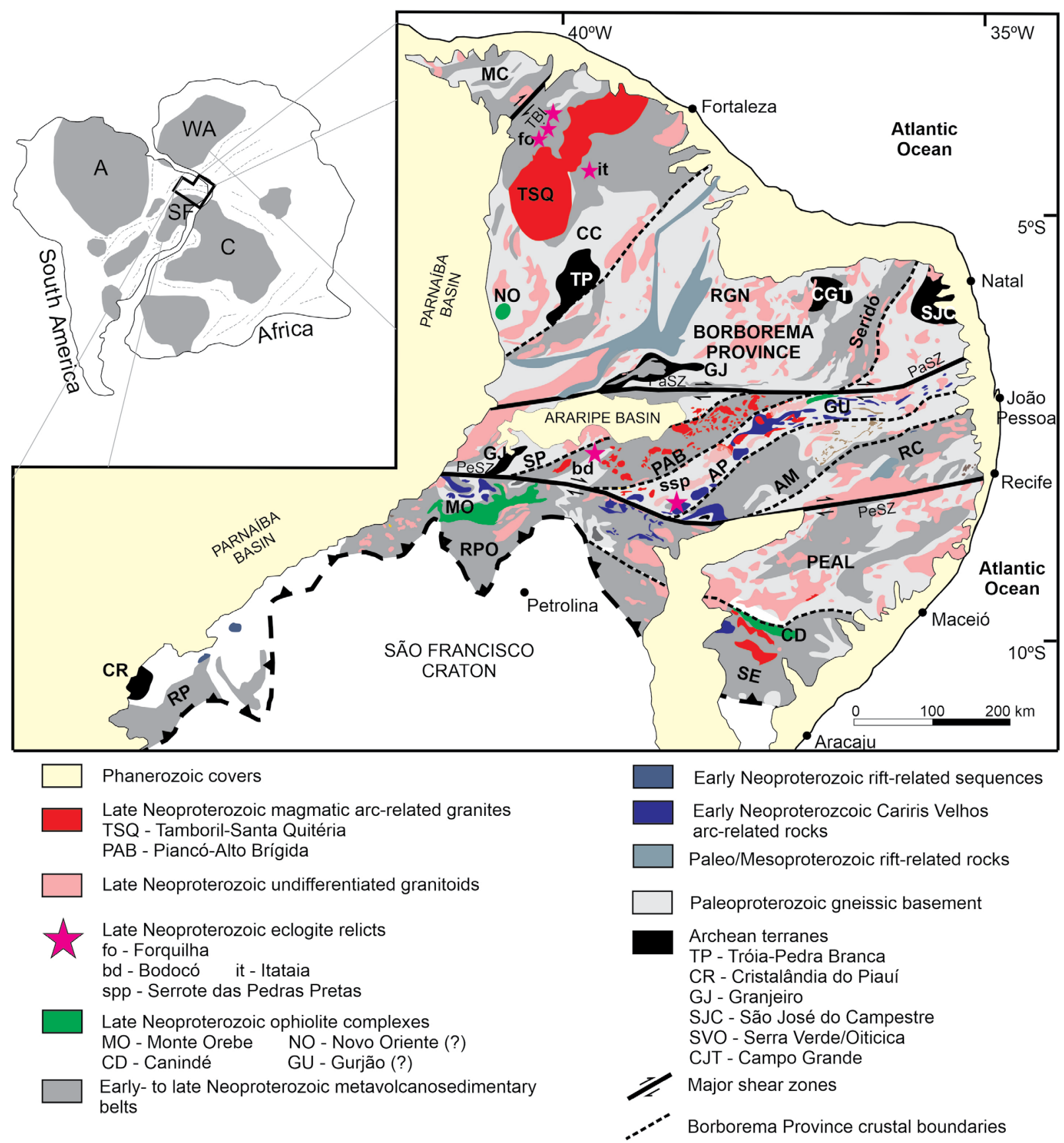

MC: Médio Coreaú; CC: Ceará Central; RGN: Rio Grande do Norte; SP: São Pedro; PAB: Piancó-Alto Brígida; AP: Alto Pajeú; AM: Alto Moxotó; RC: Rio Capibaribe; PEAL: Pernambuco Alagoas; SE: Sergipano; RPO: Riacho do Pontal; RP: Rio Preto; TBL: Transbrasiliano; PaSZ: Patos; PeSZ: Pernambuco. Source: Caxito et al. (2020a).

Figure 2. Simplified geological framework of the Borborema Province and adjacent areas. 


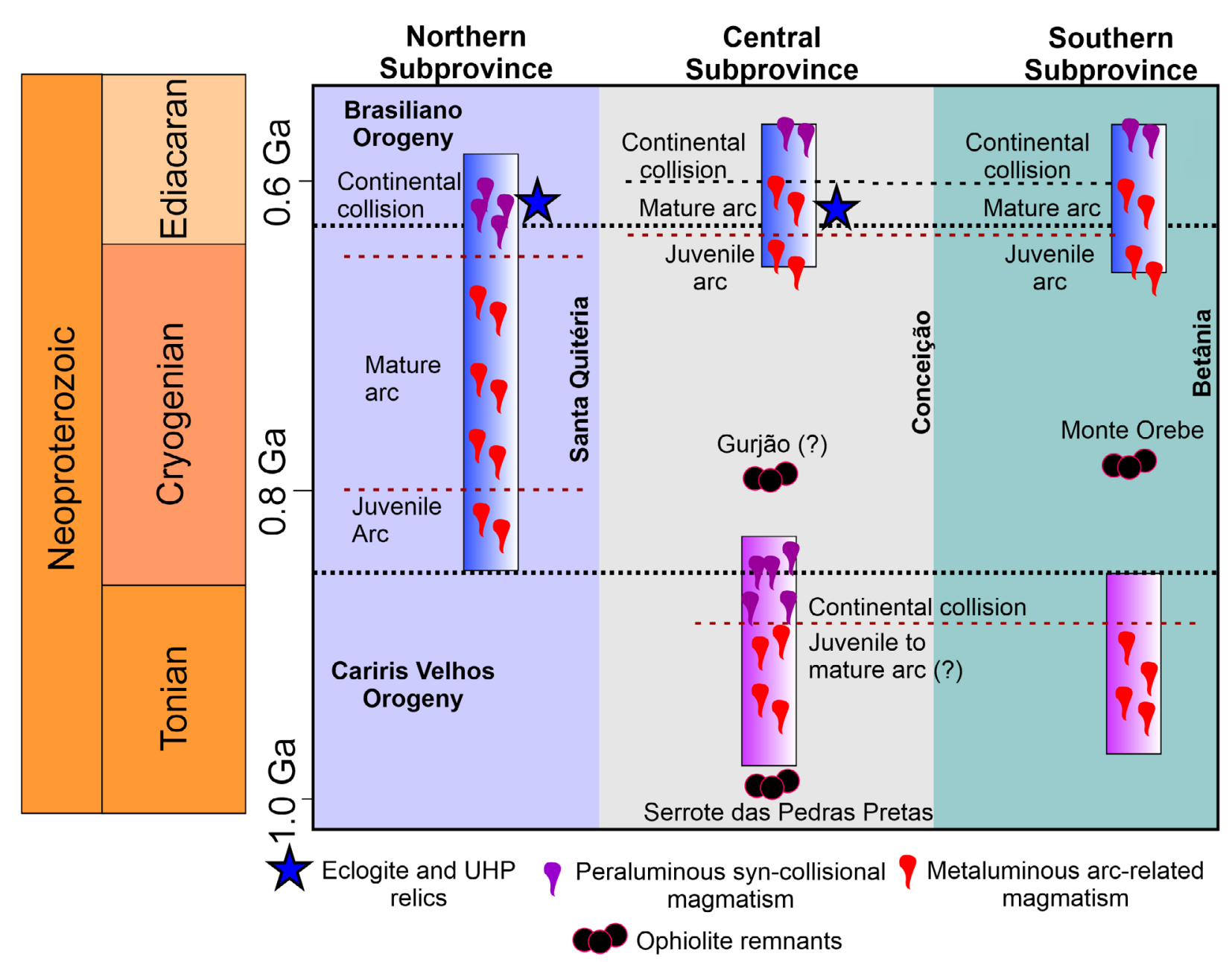

Figure 3. Timeframe of the main accretionary markers during the Neoproterozoic in the Borborema Province.

continental arc batholith of similar age in the NW border of the $\mathrm{BP}$ is interpreted as the telltale of a collisional suture related to the closure of the Goiás-Pharusian Ocean (Cordani et al.2013).

Dismembered ophiolite and possible ophiolite remnants are distributed in the internal and southern portions of the $\mathrm{BP}$, although highly reworked due to the strong deformation imposed by the late-stage strike-slip corridors. For instance, the Monte Orebe Complex in the Riacho do Pontal Orogen (RPO) comprises an association of metabasaltic and metasedimentary rocks, including exhalative rocks and minor metaultramafic bodies, with MORB-like geochemistry and suprachondritic $\varepsilon_{\mathrm{Nd}}(\mathrm{t})$ values of ca. +4.5 (Caxito et al. 2014). The outcrop region of the Monte Orebe Complex is marked by a paired positive-negative Bouguer anomaly separating two lithospheric blocks of distinct density and composition (Caxito et al.2014), also revealed by the geochronological and isotopic patterns, e.g., the presence of Cariris-Velhos (1,000-920 Ma) related rocks in the internal portion of the RPO that are inexistent in the Gavião block of the São Francisco Craton (Caxito et al. 2014). The gathered geological, geochemical, geophysical, and geochronological evidence led Caxito et al. (2016) to suggest that this portion of the RPO would be a trustful testimony of late Neoproterozoic collision between the blocks composing the BP (upper plate) and the São Francisco paleocontinent (lower plate).
Other evidence for Neoproterozoic plate tectonic processes in the BP are more contentious and highly discussed (Lima et al. 2018, Caxito et al.2020b). For example, the Cariris Velhos belt of the Transversal Zone has been proposed as an accretionary orogen, developed in a continental arc setting (Santos et al.2010,2019), including metavolcanics, metasedimentary, and metaplutonic members. Recently, Fe-Ti-V mineralized metamafic-ultramafic rocks that occur in the Floresta Region (Alto Pajeú Terrane of the Central Borborema Province) were dated at ca. 1.0 Ga (Lages and Dantas 2016), being submitted to granulitic/eclogitic metamorphism during the Brasiliano orogeny, at ca. $625 \mathrm{Ma}$. An important aspect outlined by these authors is the extremely primitive nature of the original picritic melts, which would be linked to early magmatic accumulation in a suprasubduction zone.

In the past years, petrological, geochemical, and isotopic evidence is piling up, suggesting that a large number of granitic batholiths and stocks intruded in the BP mainly in the 635-600 Ma interval could also represent continental arc settings (Sial and Ferreira 2016). The most emblematic example is the ENE-WSW trend, $750 \mathrm{~km}$ long and up to $140 \mathrm{~km}$ wide Conceição magmatic arc of the Piancó-Alto Brigída Fold Belt in the Central BP (Brito Neves et al. 2014, 2016). About 90 different I-type plutonic bodies cover a large compositional range including "normal" calc-alkaline 
epidote-bearing, high-K calc alkaline and shoshonitic series, covering the spectrum of continental arc magmatism (Eyuboglu et al.2011). It is speculated that such arc existed from 635 to $580 \mathrm{Ma}$, partially fitting with other Ediacaran subduction-related associations such as those from the Santa Quitéria Complex to the north and the Betânia arc to the south (see Caxito et al.2020a for detailed comparisons). The close association of the roots of this ancient magmatic arc with the Patos Shear Zone led Brito Neves et al. (2016) to consider this structure as a former boundary transform, thus, marking another paleo-suture zone.

Isotopic contrasts, specially using the Sm-Nd method, have also been used to mark different sources in the distinct domains as well as growth or recycling episodes of the crustal pieces of the BP. For instance, dense distribution of $\mathrm{Sm}-\mathrm{Nd}$ data on a possible terrane boundary is presented by Santos et al. (2018) to mark an early to late Neoproterozoic reworked suture between the Alto Moxotó and Alto Pajeú terranes of the Central BP, that also differ in a number of aspects such as age, magnetic, and gamma-espectrometic geophysical anomalies (Santos et al.2017b). A recent and robust work presented by Ferreira et al. (2020), combining U-Pb, Sm-Nd, petrological and geophysical data, demonstrated that the Campo Grande Block (Rio Grande do Norte Domain, northern subprovince) has grown from the Archean until the late Neoproterozoic via successive subduction and collision episodes, marking one of the most long-lived accretionary histories of the West Gondwana orogens.

A number of papers discussing the regional geophysical characteristics of the BP represent a new frontier on the overview of the BP lithospheric evolution. The approach presented by Oliveira and Medeiros (2018) covered magnetometric and gravimetric data, mostly reinforcing or reinterpreting previously defined crustal boundaries with emphasis on the regional Transbrasiliano, Pernambuco, and Patos shear zones. The alternation of geophysical anomalies between high-density/high-susceptibility with low-density/low-susceptibility deep-rooted crustal subdomains as well as the shear zone signatures are regarded as evidence for terrane amalgamation throughout the BP. The importance of the inner structures such as (at least part of) the Pernambuco Shear Zone have been also supported by seismic (Lima et al. 2015) and magnetotelluric profiles (Padilha et al. 2016) and by Curie Surface studies (Santos et al. 2014, Padilha et al. 2014, Correa et al. 2016), supporting amalgamation of distinct blocks, probably through accretion/collision of terranes.

Considering the exposed evidence based on previous literature data, it is possible to speculate how accretion events took place in this part of West Gondwana. Assembly of Archean and Paleoproterozoic blocks and microcontinents might have been triggered by convergence along the continental margins of major cratons, including the São Francisco, Amazonian, and West Africa cratons (Fig. 4A). According to Caxito et al. (2020a) and several references therein, the embrionary northern subprovince of the BP could have been part of a single block of the Benino-Nigerian Shield, labelled NOBO-BENI, that was assembled to several other crustal terranes during an oceanic stage whose suture would nucleate part of the future Patos Lineament, the latter including the Alto Moxotó, Alto Pajeú (Cariris Velhos Belt) and Rio Capibaribe terranes. Although Caxito et al. (2020a) grouped these blocks with the Adamawa-Yadé domain of Cameroon, labelled APAMCAPAY block, the juxtaposition of these terranes at that time is still speculative. Lastly, obducted ophiolite remnants and exhumed lower crust fragments such as ultra-high-pressure (UHP) and
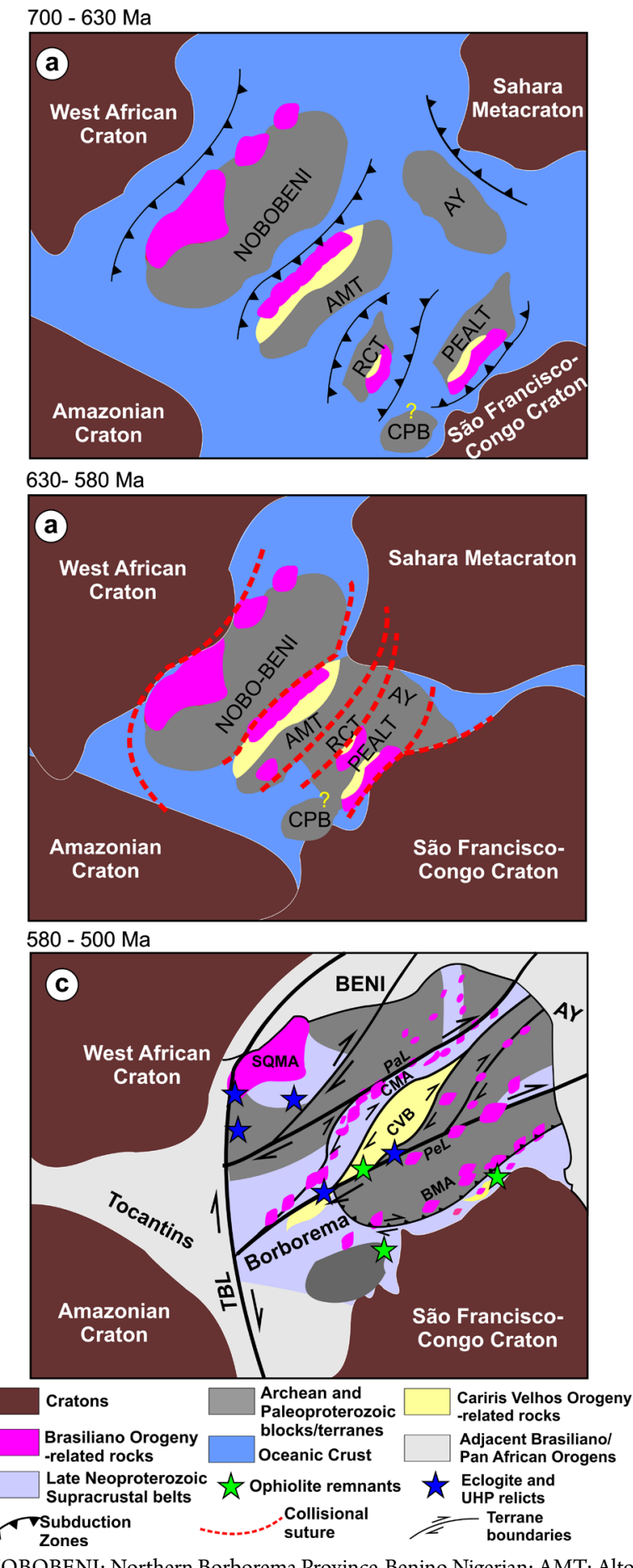

NOBOBENI: Northern Borborema Province-Benino Nigerian; AMT: Alto Moxotó; CVB: Cariris Velhos; RCT: Rio Capibaribe; PEALT: PernambucoAlagoas; AY: Adamawa-Yadé; CPB: Cristalândia do Piauí; CMA: Conceição; BMA: Betânia; TBL: Transbrasiliano; PaL: Patos; PeL: Pernambuco.

Figure 4. Schematic accretionary model proposed for the Borborema Province evolution through 700 and 500 Ma. 
eclogitic rocks are associated with the late collisional phase of the Brasiliano orogeny (Fig. 4B). With strain accommodation along the crustal boundaries, convergent tectonics were followed by strike-slip deformation reactivating the previous suture zones via extrusion tectonics (Fig. 4C).

\section{PROBLEMS AND OPEN QUESTIONS}

A major issue considering accretionary models in the Neoproterozoic of the BP is the lack of reliable evidence for crustal suture in most of its inner shear zones. For instance, the Pernambuco Shear Zone is not considered to be a single structure by some authors (Vauchez et al. 1995). Crustal continuity between the blocks separated by the eastern portion of this lineament is suggested by similar Paleoproterozoic ages and rock composition on both sides of it, thus preventing straightforward interpretation of a terrane boundary (França et al. 2019). Instead it is most likely to represent the result of nucleation on an ancient deeper structure or even a new structure developed through reworking of a single crustal block by later deformation. These characteristics led Oliveira and Medeiros (2018) to separate the Pernambuco Shear Zone into two branches, western and eastern, and Caxito et al. (2016) suggested that only the western branch was nucleated in a former oceanic domain marked by a suture zone, while the eastern branch would represent a continuation of the shear corridor through a previously continuous crustal block (the APAMCAPAY ribbon continent; Caxito et al. 2020a), such as in the present-day Gulf of California where the East Pacific Rise continues through California and connects to the Gorda Ridge on the other side.

The nature of the Cariris Velhos Event is highly debated, and some authors point to the A-type geochemistry of some of the bodies as related to within-plate events (Guimarães et al. 2016). The lack of a well-defined metamorphic event related to continental accretion at this stage is also debated (Neves 2015). Regarding the first point, Caxito et al. (2020b) propose a useful distinction between Tonian rocks related to the Cariris Velhos event at $1.0 \mathrm{Ga}-920 \mathrm{Ma}$ and those related with crustal rifting at ca. 900-860 Ma, and discuss the occurrence of extensional settings related to accretionary orogens such as back-arc basins (one representative would be the Riacho Gravatá subdomain of the Alto Pajeú domain; Kozuch 2003, Santos et al. 2010, Caxito et al.2020b). Regarding the second point, Caxito et al. (2020b) discuss the probability of soft-collision events and reworking during the extensive Brasiliano Orogeny. In addition, restricted metamorphic zircon crystals and recrystallized rims still poorly dated at ca. 1.0 Ga have been found in high-grade metamorphic rocks in the Central Borborema Province (Lages and Dantas 2016, Santos et al. 2019). In fact, for a deeper understanding of the processes occurring in the early Tonian in the BP, refined field, geological, elemental and isotopic geochemistry, and geochronological studies are necessary.

According to Neves (2018), a large ocean could not have existed along the Patos Shear Zone, because of the occurrence of early Tonian detrital zircon grains in the
Northern BP, suggesting a connection with the Central BP and sourcing from the Cariris Velhos belt, as well as the lack of clear isotopic parameters of arc-related derivation of the early Ediacaran granites. In a general sense, compilations of detrital zircon data throughout the province reveal similar age distributions with main peaks at 2.15 to $2.05 \mathrm{Ga}$, an age range that characterizes most of the $\mathrm{BP}$ basement as well as the basement of the São Francisco Craton further south. Other links between these two major crustal domains are also proposed by the occurrence of Statherian rift basins (Orós-Jaguaribeano and Espinhaço-Chapada Diamantina) and Tonian rift-related units in both of them (Caxito et al. 2020a), interpreted as suggestive of the lack of physical barriers separating the inner domains of the province during the Neoproterozoic (Neves 2015).

An alternative model recently proposed by Caxito et al. (2020a) conciliates some of these objections. In this model, the São Francisco-Congo paleocontinent and the BP basement were part of a major ancient supercontinent prior to Tonian rifting, similar to what is proposed by Cordani et al. (2013) as a "Central African Block", which would also involve part of the basement of the Tocantins and Mantiqueira Province and probably the Saharan "metacratonic" region of NW Africa. Widespread post-Cariris Tonian rifting (ca. 900-860 Ma) caused hyperextension and decratonization of large portions of the Central African Block, leading to rifting of continental fragments that would drift as ribbon continents separated by $\mathrm{V}$-shaped oceanic basins during the Neoproterozoic (such as the Transnordestino-Central African ocean testified by the Monte Orebe ophiolite) and would then be squeezed and reworked in between the major cratonic blocks during Ediacaran-Cambrian collision.

In such a model, which fits the presented speculation of this contribution, most of the basement blocks composing the BP (called therein NOBO-BENI for Northern BorboremaBenino-Nigerian and APAMCAPAY for Alto Pajeú-Alto Moxotó-Rio Capibaribe-Adamawa-Yade) would rift, drift, and then be squeezed back and collide once again approximately in the same original position due to approximation of the West African-São Luís paleocontinent, characterizing a typical introverted plate tectonics cycle, or a classical Wilson Cycle. Later, at the late Ediacaran-Cambrian transition, collision of the major Amazonian paleocontinent would reactivate deformation in the BP and cause development of the regional strikeslip network. Thus, similarity of basement ages is explained through affiliation of the ribbon continents with an ancient common parent (the Central African Block), while extreme reworking, injection of plutons and metamorphism of these basement blocks during the Brasiliano Orogeny is explained through decratonizaton and loss of the tectospheric keel, which characterizes cratonic rigidity, during the early Tonian hyperextension processes.

Taking into account this later model, one question remains as to whether the rifted blocks and ribbon continents really returned to the same original positions, or if drifting generated new paleocontinental and paleoceanic configurations, which would allow for exotic blocks, e.g. those derived from 
Rodinia, or those developed within the newly-born oceanic domains, to collide with the once conjugated continental margins. Geological, geophysical, isotopic, and geochronological studies are necessary to better characterize the distinct blocks and check if some of them could have an origin that is completely allocthonous with respect to a former Central African Block. One of the best candidates is the Cariris Velhos Belt, which represents a setting of early Tonian rocks distinct from any other, composing the basement of the blocks derived from the hypothetical Central African Block. Other fragments have also been proposed as probable remnants of Columbia (Brito Neves et al.2020). These elements are key to conciliate between the introverted Wilson Cycle models, the extroverted accretionary models, and the intracontinental reworking models proposed for portions of the BP.

\section{ACKNOWLEDGMENTS}

This contribution was possible due to the encouragement of several colleagues from the Brazilian Geological Society. LCMLS acknowledges the support given by the Instituto Nacional de Ciência e Tecnologia (INCT) para Estudos Tectônicos. FAC acknowledges CNPq for his Research Productivity Grant. The numerous contributions given by Prof. Reinhardt A. Fuck and an anonymous reviewer are strongly appreciated as well as those from Monica Heilbron and Claudio Riccomini.

\section{ARTICLE INFORMATION}

Manuscript ID: 20200104. Received on: 08/16/2020. Approved on: 11/30/2020.

L.C.M.L.S. wrote the first draft of the manuscript and prepared Figures 1, 3, and 4; F.A.C. improved the original manuscript by adding new statements, in addition to preparing Figure 2.

Competing interests: The authors declare no competing interests.

\section{REFERENCES}

Almeida F.F.M., Hasui, Y., Brito Neves B.B., Fuck R.A. 1981. Brazilian structural provinces: An introduction. Earth Science Reviews, 17(1-2):1-29. https://doi.org/10.1016/0012-8252(81)90003-9

Amaral W.S., Santos T.J.S., Wernick E. 2011. Occurrence and geochemistry of metamafic rocks from the Forquilha Eclogite Zone, Central Ceará (NE Brazil): geodynamic implications. Geological Journal, 46(2-3):137-155. https://doi.org/10.1002/gj.1224

Amaral W.S., Santos T.J.S., Wernick E., Nogueira Neto J.D.A., Dantas E.L., Matteini M. 2012. High-pressure granulites from Cariré, Borborema Province, NE Brazil: tectonic setting, metamorphic conditions and $\mathrm{U}-\mathrm{Pb}$, $\mathrm{Lu}-\mathrm{Hf}$ and Sm-Nd geochronology. Gondwana Research, 22(3-4):892-909. https://doi.org/10.1016/j.gr.2012.02.011

Archanjo C.J., Hollanda M.H.B.M., Rodrigues S.W., Brito Neves B.B., Armstrong R. 2008. Fabrics of pre- and syntectonic granite plutons and chronology of shear zones in the Eastern Borborema Province, NE Brazil. Journal of Structural Geology, 30(3):310-326. https://doi.org/10.1016/j.jsg.2007.11.011

Brito Neves B.B. 2019. Terrenos Tectonoestratigráficos e / ou "Maciços". Evolução do conceito e aplicação na Zona Transversal da Província Borborema. Terrae Didatática, 15:e019020. https://doi.org/10.20396/td.v15i0.8655818

Brito Neves B.B., Fuck R.A., Pimentel M.M. 2014. The Brasiliano collage in South America: A review. Brazilian Journal of Geology, 44(3):493-518. https://doi.org/10.5327/Z2317-4889201400030010

Brito Neves B.B., Santos E.J., Fuck R.A., Santos L.C.M.L. 2016. A preserved early Ediacaran magmatic arc at the northernmost portion of the Transversal Zone central subprovince of the Borborema Province, Northeastern South America. Brazilian Journal of Geology, 46(4):491-508. https://doi. org/10.1590/2317-4889201620160004

Brito Neves B.B., Santos E.J., Van Schmus W.R. 2000. Tectonic history of the Borborema province. In: Cordani U.G., Milani E.J., Thomaz Filho A., Campos D.A. (Eds.). Tectonic Evolution of South America. Rio de Janeiro: 31st International Geological Congress, p. 151-182.

Brito Neves B.B., Silva Filho A.F. 2019. Superterreno Pernambuco-Alagoas (PEAL) na Província Borborema: ensaio e regionalização tectônica. Geologia USP. Série Científica, 19(2):3-28. https://doi.org/10.11606/ issn.2316-9095.v19-148257

Brito Neves B.B., Van Schmus W.R., Santos L.C.M.L. 2020. Alto Moxotó Terrane, a fragment of Columbia Supercontinent in the interior of the Transversal Zone, Borborema Province, Northeast Brazil. Brazilian Journal of Geology, 50(2):e20190077. https://doi. org/10.1590/2317-4889202020190077
Brown M., Johnson T. 2019. Metamorphism and the evolution of subduction on Earth. American Mineralogist, 104(8):1065-1082. https:// doi.org/10.2138/am-2019-6956

Caxito F.A., Santos L.C.M.L., Ganade C.E., Bendaoud A., Fettous E.-H., Bouyo M.H. 2020a. Toward an integrated model of geological evolution for NE Brazil-NW Africa: The Borborema Province and its connections to the Trans-Saharan (Benino-Nigerian and Tuareg shields) and Central African orogens. Brazilian Journal of Geology, 50(2):e20190122. https:// doi.org/10.1590/2317-4889202020190122

Caxito F.A., Santos L.C.M.L., Uhlein A., Dantas E.L., Alkmim A.R., Lana C. 2020b. New U-Pb (SHRIMP) and first Hf isotope constraints on the Tonian (1000-920 Ma) Cariris Velhos event, Borborema Province, NE Brazil. Brazilian Journal of Geology, 50(2):e20190082. https://doi. org/10.1590/2317-4889202020190082

Caxito F.A., Uhlein A., Dantas E.L., Stevenson R., Pedrosa-Soares A.C. 2015 Orosirian (ca. $1.96 \mathrm{Ga}$ ) mafic crust of the northwestern São Francisco Craton margin: Petrography, geochemistry and geochronology of amphibolites from the Rio Preto fold belt basement, NE Brazil. Journal of South American Earth Sciences, 59:95-111. https://doi.org/10.1016/j.jsames.2015.02.003

Caxito F.A., Uhlein A., Dantas E.L., Stevenson R., Salgado S.S., Dussin I., Sial A.N., 2016. A complete Wilson Cycle recorded within the Riacho do Pontal Orogen, NE Brazil: Implications for the Neoproterozoic evolution of the Borborema Province at the heart of West Gondwana. Precambrian Research, 282:97-120. https://doi.org/10.1016/j.precamres.2016.07.001

Caxito F., Uhlein A., Stevenson R., Uhlein G.J. 2014. Neoproterozoic oceanic crust remnants in northeast Brazil. Geology, 42(5):387-390. https://doi.org/10.1130/G35479.1

Coney P., Jones D., Monger J. 1980. Cordilleran suspect terranes. Nature, 288:329-333. https://doi.org/10.1038/288329a0

Cordani U.G., Pimentel M.M., Araújo C.E.G., Fuck R.A. 2013. The significance of the Transbrasiliano-Kandi tectonic corridor for the amalgamation of West Gondwana. Brazilian Journal of Geology, 43(3):583597. https://doi.org/10.5327/Z2317-48892013000300012

Correa R.T., Vidotti R.M., Oksum E. 2016. Curie surface of Borborema Province, Brazil. Tectonophysics, 679:73-87. https://doi.org/10.1016/j.tecto.2016.04.037

Cruden A.R., Weinberg R.F. 2018. Mechanisms of magma transport and storage in the lower and middle crust-magma segregation, ascent and emplacement, in: Volcanic and Igneous Plumbing Systems: Understanding Magma Transport, Storage, and Evolution in the Earth's Crust. Volcanic and Igneous Plumbing Systems, 13-53. https://doi.org/10.1016/B978-0-12-809749-6.00002-9 
Dantas E.L., Souza Z.S., Wernick E., Hackspacher P.C., Martin H., Xiaodong D., Li J.W. 2013. Crusta growrh in the 3.4-2.7 Ga São José do Campestre Massif, Borborema Province, NE Brazil. Precambrian Research, 227:120156. https://doi.org/10.1016/j.precamres.2012.08.006

Eyuboglu Y., Santosh M., Dudas F.O., Chung S.L., Akaryali E. 2011. Migrating magmatism in a continental arc: Geodynamics of the Eastern Mediterranean revisited. Journal of Geodynamics, 52(1):11-15. https://doi. org/10.1016/j.jog.2010.11.006

Ferreira A.C.D., Dantas E.L., Fuck R.A., Nedel I.M. 2020. Arc accretion and crustal reworking from late Archean to Neoproterozoic in Northeast Brazil. Nature Scientific Report, 10:7855. https://doi.org/10.1038/ s41598-020-64688-9

Fetter A.H., Santos T.S.S., Schmus W.R.V., Hackspacher P.C., Brito Neves B.B., Arthaud M.H., Nogueira Neto J.A., Wernick E. 2003. Evidence for Neoproterozoic continental arc magmatism in the Santa Quitéria Batholith of Ceará State, NW Borborema province, NE Brazil. Implication for the assembly of West Gondwana. Gondwana Research, 6(2):265-273. https:// doi.org/10.1016/S1342-937X(05)70975-8

França R.H.M., Neves S.P., Bezerra J.P.S., Bruguier O. 2019. Geochemistry and geochronology of orthogneisses across a major transcurrent shear zone (East Pernambuco shear zone, Borborema Province, Northeast Brazil): Tectonic implications. Journal of South American Earth Sciences, 91:285-301. https://doi.org/10.1016/j.jsames.2019.02.015

French S.W., Romanowicz B. 2015. Broad plumes rooted at the base of the Earth's mantle beneath major hotspots. Nature, 525:95-99. https://doi. org/10.1038/nature 14876

Ganade de Araújo C.E., Basei M., Grandjean F.C., Armstrong R., Brito R.S. 2017. Contrasting Archaean (2.85-2.68 Ga) TTGs from the Tróia Massif (NE-Brazil) and their geodynamic implications for flat to steep subduction transition. Precambrian Research, 297:1-18. https://doi.org/10.1016/j. precamres.2017.05.007

Ganade de Araújo C.E., Rubatto D., Hermann J., Cordani U.G., Caby R., Basei M.A.S. 2014a. Ediacaran 2,500-km-long synchronous deep continental subduction in the West Gondwana Orogen. Nature Communications, 5:5198. https://doi.org/10.1038/ncomms6198

Ganade de Araújo C.E., Weinberg R.F., Cordani U.G. 2014b. Extruding the Borborema Province (NE-Brazil): A two-stage Neoproterozoic collision process. Terra Nova, 26(2):157-168. https://doi.org/10.1111/ter.12084

Guimarães I.P., Brito M.F.L., Lages G.A., Silva Filho A.F., Santos L., Brasilino R.G. 2016. Tonian granitic magmatism of the Borborema Province, NE Brazil: A review. Journal of South American Earth Sciences, 68:97-112. https://doi.org/10.1016/j.jsames.2015.10.009

Guimarães I.P., Silva Filho A.F., Almeida C.N., Van Schmus W.R., Araújo J.M.M., Melo S.C., Melo E.B. 2004. Brasiliano (Pan-African) granitic magmatism in the Pajeú-Paraíba belt, Northeast Brazil: an isotopic and geochronological approach. Precambrian Research, 135(1-2):23-53. https://doi.org/10.1016/j.precamres.2004.07.004

Heilbron M., Valeriano C.M., Tassinari C.C.G., Almeida J., Tupinambá M., Siga J., Trouw R. 2008. Correlation of neoproterozoic terranes between the Ribeira Belt, SE Brazil and its African counterpart: Comparative tectonic evolution and open questions. Geological Society Special Publication, 294(1):211-237. https://doi.org/10.1144/SP294.12

Hollanda M.H.B.M., Archanjo C.J., Souza L.C., Dunyi L., Armstrong R.A. 2011. Long-lived Paleoproterozoic granitic magmatism in the SeridóJaguaribe Domain, Borborema Province-NE Brazil. Journal of South American Earth Sciences, 32(4):287-300. https://doi.org/10.1016/j. jsames.2011.02.008

Howell D.G. 1995. Principles of terrane analysis: new applications for the Global Tectonics. 2. ed. London: Chapman \& Hall. 235 p.

Kozuch M. 2003. Isotopic and trace element geochemistry of early Neoproterozoic gneissic and metavolcanic rocks in the Cariris Velhos orogen of the Borborema Province, Brazil, and their bearing on tectonic setting. PhD Thesis, University of Kansas, Lawrence, 199 p.

Lages G.A., Dantas E.L. 2016. Floresta and Bodocó Mafic-Ultramafic Complexes, western Borborema Province, Brazil: Geochemical and isotope constraints for evolution of a Neoproterozoic arc environment and retroeclogitic hosted Ti-mineralization. Precambrian Research, 280:95-119. https://doi.org/10.1016/j.precamres.2016.04.017
Lima H.M., Pimentel M.M., Fuck R.A., Santos L.C.M.L., Dantas E.L. 2018. Geochemical and detrital zircon geochronological investigation of the metavolcanosedimentary Araticum complex, sergipano fold belt: Implications for the evolution of the Borborema Province, NE Brazil. Journal of South American Earth Sciences, 86:176-192. https://doi.org/10.1016/j. jsames.2018.06.013

Lima H.M., Pimentel M.M., Santos L.C.M.L., Dantas E.L. 2019. Isotopic and geochemical characterization of the metavolcano-sedimentary rocks of the Jirau do Ponciano Dome: a structural window to a Paleoproterozoic arc root within the Southern Borborema Province, Northeast Brazil. Journal of South American Earth Sciences, 90:54-69. https://doi.org/10.1016/j. jsames.2018.12.002

Lima M.V.A.G., Berrocal J., Soares J.E.P., Fuck R.A. 2015. Deep seismic refraction experiment in northeast Brazil: New constraints for Borborema Province evolution. Journal of South American Earth Sciences, 58:335-349. https://doi.org/10.1016/j.jsames.2014.10.007

Meira V.T., Garcia-Casco A., Hyppolito T., Juliani C., Schorscher J.H.D. 2019. Tectono-Metamorphic Evolution of the Central Ribeira Belt, Brazil: A Case of Late Neoproterozoic Intracontinental Orogeny and Flow of Partially Molten Deep Crust During the Assembly of West Gondwana. Tectonics, 38(8):3182-3209. https://doi.org/10.1029/2018TC004959

Neves S.P. 2003. Proterozoic history of the Borborema province (NE Brazil): Correlations with neighboring cratons and Pan-African belts and implications for the evolution of western Gondwana. Tectonics, 22(4):1031. https://doi.org/10.1029/2001TC001352

Neves S.P. 2015. Constraints from zircon geochronology on the tectonic evolution of the Borborema Province (NE Brazil): Widespread intracontinental Neoproterozoic reworking of a Paleoproterozoic accretionary orogen. Journal of South American Earth Sciences, 58:150-164. https://doi.org/10.1016/j.jsames.2014.08.004

Neves S.P. 2018. Comment on "A preserved early Ediacaran magmatic arc at the northernmost part of the transversal zone-Central domain of the Borborema Province, Northeast of South America", by B. B. de Brito Neves et al. (2016). Brazilian Journal of Geology, 48(3):623-630. https://doi. org/10.1590/2317-4889201820180049

Oliveira E.P., Windley B.F., Araújo M.N.C. 2010. The Neoproterozoic Sergipano orogenic belt, NE Brazil: a complete plate tectonic cycle in western Gondwana. Precambrian Research, 181(1-4):64-84. https://doi. org/10.1016/j.precamres.2010.05.014

Oliveira R.G., Medeiros W.E. 2018. Deep crustal framework of the Borborema Province, NE Brazil, derived from gravity and magnetic data. Precambrian Research, 315:45-65. https://doi.org/10.1016/j. precamres.2018.07.004

Padilha A.L., Vitorello Í., Pádua M.B., Bologna M.S. 2014. Electromagnetic constraints for subduction zones benearth the northwest Borborema Province: Evidence for Neoproterozoic island arc-continent collision in northeast Brazil. Geology, 42(1):91-94. https://doi.org/10.1130/G34747.1

Padilha A.L., Vitorello Í., Pádua M.B., Fuck R.A. 2016. Deep magnetotelluric signatures of the early Neoproterozoic Cariris Velhos tectonic event within the Transversal sub-province of the Borborema Province, NE Brazil. Precambrian Research, 275:70-83. https://doi.org/10.1016/j. precamres.2015.12.012

Santos A.C.L., Padilha A.L., Fuck R.A., Pires A.C.B., Vitorello I., Pádua M.B. 2014. Deep structure of a stretched lithosphere: Magnetotelluric imaginf of the southeastern Borborema Procince, NE Brazil. Tectonophysics, 610:3850. https://doi.org/10.1016/j.tecto.2013.10.008

Santos E.J. 1996. Ensaio preliminar sobre terrenos e tectônica acrescionária na Província Borborema. In: Congresso Brasileiro de Geologia, 39., Salvador. Annals... 6:47-50.

Santos E.J., Medeiros V.C. 1999. Constraints from granitic plutonism on Proterozoic crustal growth of the Transverse Zone, Borborema Province, Northeast Brazil. Revista Brasileira de Geociências, 29(1):73-84. https://doi. org/10.25249/0375-7536.1999297384

Santos E.J., Souza Neto J.A., Carmona L.C.M., Armstrong R., Santos L.C.M.L., Mendes L.U.D.S. 2013. The metacarbonate rocks of Itatuba (Paraíba): a record of sedimentary recycling in a Paleoproterozoic collision zone of the Borborema Province, NE Brazil. Precambrian Research, 224:454471. https://doi.org/10.1016/j.precamres.2012.09.021 
Braz. J. Geol. (2021), 51(2): e20200104

Santos E.J., Van Schmus W.R., Kozuch M., Brito Neves B.B. 2010. The Cariris Velhos tectonic event in Northeast Brazil. Journal of South American Earth Sciences, 29(1):61-76. https://doi.org/10.1016/j.jsames.2009.07.003

Santos L.C.M.L., Dantas E.L., Cawood P.A., Lages G.A., Lima H.M., Santos E.J. 2018. Accretion Tectonics in Western Gondwana Deduced From SmNd Isotope Mapping of Terranes in the Borborema Province, NE Brazil. Tectonics, 37(8):2727-2743. https://doi.org/10.1029/2018TC005130

Santos L.C.M.L., Dantas E.L., Cawood P.A., Lages G.A., Lima H.M., Santos E.J., Caxito F.A. 2019. Early to late Neoproterozoic subduction-accretion episodes in the Cariris Velhos Belt of the Borborema Province, Brazil: Insights from isotope and whole-rock geochemical data of supracrustal and granitic rocks. Journal of South American Earth Sciences, 96:102384. https:// doi.org/10.1016/j.jsames.2019.102384

Santos L.C.M.L., Dantas E.L., Cawood P.A., Santos E.J., Fuck R.A. 2017a. Neoarchean crustal growth and Paleoproterozoic reworking in the Borborema Province, NE Brazil: Insights from geochemical and isotopic data of TTG and metagranitic rocks of the Alto Moxotó Terrane. Journal of South American Earth Sciences, 79:342-363. https://doi.org/10.1016/j. jsames.2017.08.013

Santos L.C.M.L., Dantas E.L., Santos E.J., Santos R.V., Lima H.M. 2015. Early to late Paleoproterozoic magmatism in NE Brazil: The Alto Moxotó Terrane and its tectonic implications for the pre-West Gondwana assembly. Journal of South American Earth Sciences, 58:188-209. http://doi. org/10.1016/j.jsames.2014.07.006

Santos L.C.M.L., Dantas E.L., Vidotti R.W., Cawood P.A., Santos E.J., Fuck R.A., Lima H.M. 2017b. Two-stage terrane assembly in Western Gondwana: Insights from structural geology and geophysical data of central Borborema Province, NE Brazil. Journal of Structural Geology, 103:167-184. https:// doi. org/10.1016/j.jsg.2017.09.012

Santos T.J.S., Amaral W.S., Ancelmi M.F., Pitarello M.Z., Fuck R.A., Dantas E.L. 2015. U-Pb age of the coesite-bearing eclogite from NW Borborema
Province, NE Brazil: Implications for western Gondwana assembly. Gondwana Research, 28(3):1183-1196. https://doi.org/10.1016/j. gr.2014.09.013

Sial A.N., Ferreira V.P. 2016. Magma associations in Ediacaran granitoids of the Cachoeirinha-Salgueiro and Alto Pajeú terranes, northeastern Brazil: Forty years of studies. Journal of South American Earth Sciences, 68:113-133. https://doi.org/10.1016/j.jsames.2015.10.005

Silva Filho A.F., Guimarães I.P., Santos L., Armstrong R., Van Schmus W.R. 2016. Geochemistry, U-Pb geochronology, Sm-Nd and O isotopes of $\mathrm{ca} .50$ Ma long Ediacaran High-K Syn-collisional magmatism in the Pernambuco Alagoas Domain, Borborema Province, NE Brazil. Journal of South American Earth Sciences, 68:134-154. https://doi.org/10.1016/j.jsames.2015.12.013

Tetreault J.L., Buiter J.H. 2014. Future accreted terranes: a compilation of island arcs, oceanic plateaus, submarine ridges, seamounts, and continental fragments. Solid Earth, 5:1243-1275. https://doi.org/10.5194/ se-5-1243-2014

Van Hunen J., Moyen J.F. 2012. Archean subduction: Fact or fiction? Annual Review on Earth and Planetary Sciences, 40:195-219. https://doi. org/10.1146/annurev-earth-042711-105255

Van Schmus W.R., Brito Neves B.B., Hackspacher P., Baninski M. 1995. U/ $\mathrm{Pb}$ and $\mathrm{Sm} / \mathrm{Nd}$ geochronologic studies of eastern Borborema Province, northeastern Brazil: initial conclusions. Journal of South American Earth Sciences, 8(3-4):276-288.https://doi.org/10.1016/0895-9811(95)00013-6

Vauchez A., Neves S.P., Caby R., Corsini M., Egydio-Silva M., Arthaud M., Amaro V. 1995. The Borborema shear zone system, NE Brazil. Journal of South American Earth Sciences, 8(3-4):247-266. https://doi. org/10.1016/0895-9811(95)00012-5

Viegas L.G.F., Archanjo C.J., Hollanda M.H.B.M., Vauchez A. 2014 Microfabrics and zircon U-Pb (SHRIMP) chronology of mylonites from the Patos shear zone (Borborema Province, NE Brazil). Precambrian Research, 243:1-17. https://doi.org/10.1016/j.precamres.2013.12.020 